\title{
Community Policing, Workplace Structure and Attitudes Toward Lesbians and Gay Men and their Civil Liberties
}

\author{
Mary Bernstein *and Stephen Wulff
}

\author{
Department of Sociology, University of Connecticut, USA
}

\begin{abstract}
While criminal justice workplaces, such as the police and prisons, are noted for reproducing both gender inequality and inequality based on sexuality or sexual orientation, this paper examines whether reorganizing the workplace can alter those interactions and reduce inequality. We draw on survey data from a police department to theorize the likely impact of the move toward community policing and rehabilitative models of justice on the attitudes of heterosexual sworn officers and civilian employees toward lesbians and gay men and their civil rights. Our analysis shows that sworn officers and civilian employees' attitudes toward community policing and rehabilitation significantly affect their views on lesbians and gay men and their civil liberties both directly and indirectly. We conclude by suggesting the policy implications of our findings and avenues for future research.
\end{abstract}

Keywords: Sexual Orientation and Policing, Gender, Workplace Inequality, Lesbians and Gay Men in Policing.

Workplaces have long been studied as sites where inequality is reproduced by systematic practices within organizations (Acker 2006). Criminal justice workplaces, such as the police and prisons, are noted for reproducing both gender inequality (Martin and Jurik 1996) and inequality based on sexuality or sexual orientation (Bernstein 2004). But if workplace interactions produce and reproduce inequality, can reorganizing the workplace alter those interactions and reduce inequality? In this paper, we draw on survey data from a police department to theorize the likely impact of the move toward community policing and rehabilitative models of justice on the attitudes of heterosexual sworn officers and civilian employees toward lesbians and gay men and their civil rights.

Historically, the police have been hostile toward the lesbian and gay community, enforcing laws that once made homosexuality illegal, expressing strong dislike for lesbians and gay men, and opposing the hiring of lesbian and gay officers (Bernstein 2004). However, in recent years police departments have made efforts to reach out to the LGBT community by creating gay and lesbian liaison units and hiring lesbian and gay officers (Gillespie 2008).

Other, less direct changes in policing may also have an effect on police department employees' attitudes toward lesbians and gay men and their civil rights. Specifically, the move within police departments since the 1980s beyond bureaucratic and professional forms of policing toward community policing models and the "personalization of service" (Kelling and Moore 1991)

*Address correspondence to this author at the Department of Sociology, University of Connecticut, USA; Tel: 860-486-3991; Fax: 860-486-6356;

E-mail: Mary.Bernstein@uconn.edu may make the police more accepting of different types of people. Making this change from bureaucratic to community policing involves a reorientation among officers, one in which officers must move beyond conventional policing strategies of surveillance and arrest (Rosenbaum and Lurigio 1994) and instead focus on addressing community problems, referring citizens to social service organizations, and resolving conflicts among local citizens (Trojanowicz 1986). In response to these changes, a number of studies have examined police officers' attitudes toward community policing, and some studies have revealed a positive relationship between male police officers' attitudes toward community policing and their attitudes toward women (DeLong 1997; Sims, Scarborough, and Ahmad 2003). Yet to our knowledge, no prior study has considered whether concrete structural changes in a police department (e.g., adoption of community policing and rehabilitation models) could lead to meaningful change in heterosexual police employees' attitudes toward gay men and lesbians.

In light of this shift away from traditional policing practices to more community-oriented models that incorporate and respect diversity (Colvin 2012), could the re-structuring of a workplace affect the attitudes of its workers? Specifically, what can police officers' attitudes toward community policing and rehabilitation tell us about their attitudes toward gay men and lesbians? In this paper, using original survey data from a police department in the Southwest (Bernstein and Kostelac 2002), we explore the relationship between police department employees' attitudes toward community policing and rehabilitative models of justice on the one hand and their views on lesbians and gay men and their civil rights on the other. 
In the next section, we briefly examine the factors that have already been shown to influence attitudes toward lesbians and gay men and their civil rights. We then examine the shift to community policing and the civilianization of the police force and develop and test hypotheses regarding the relationship between these workplace changes and various attitudes toward lesbians and gay men. Our analysis shows that sworn officers and civilian employees' attitudes toward community policing and rehabilitation significantly affect their views on lesbians and gay men and their civil liberties both directly and indirectly. We conclude by suggesting the policy implications of our findings and avenues for future research.

\section{LITERATURE REVIEW}

We are interested in examining how structural aspects of criminal justice workplaces may influence attitudes regarding sexual orientation. The perceptions that employees have of their workplace environment can have serious consequences for the organization and become barriers or points of access that help establish and maintain negative or positive differences among workers (Bolton 2003). Extending Omi and Winant's (1994) notion of "racial project," Adam (1998) argues that scholars should consider the myriad sexual projects that emerge in local contexts as a result of histories, experiences, structural factors, and the diffusion of idea systems and ways in which actors deploy discourses. Some studies in the area of "new institutionalism" find that contextual variables and organizational structure may influence a number of attitudes within discrete workplaces (Kanter 1977; Bernstein and Kostelac 2002) and among partnered and inter-agency workplaces (Monro 2007). In their theory of fields, Fligstein and McAdam (2011:20) develop a general perspective to explain how new meso-level social orders emerge and stabilize and existing ones become transformed. New definitions, they argue, can reshape organizations and alter the rules of the game, thus redefining the positions of social actors and shifting power arrangements within the organizational field (p. 5). Increasingly, scholars have begun to examine the ways in which organizational culture impacts sexual minorities (e.g., Hassell and Brandl 2009).

Changes in the organizational structure of policing may be viewed through the lens of Norbert Elias ([1939] 2000), or, more appropriately, Pratt's (2011) work on developments in punishment of offenders, as a civilizing or de-civilizing process that works to alter the social distance between the normatively patriarchal police department and the citizens they patrol. The civilizing process though is not teleological or "formulaic." During times of rapid social change the civilizing process within a society may accelerate or reverse when decivilizing forces taking hold (Pratt 2011:222). This Eliasian prism is useful for understanding the changing shape of social control over LGBT citizens, especially at a time when the LGBT community continues moving closer to achieving social equality, as the US undergoes profound cultural changes in its treatment and attitudes toward the LGBT community. In more recent years, police departments have made efforts to reach out to the LGBT community through the creation of gay and lesbian liaison units in city police departments like the Washington, D.C. Metropolitan Police Department and Atlanta Police Department; however, historically, relations between the gay and lesbian community and police have been tenuous. In fact, the gay liberation movement was, in large part, sparked after New York City police raided the Stonewall Inn bar in June of 1969 under the pretext that the bar did not have a proper liquor license, before proceeding to arrest gay men who were merely socializing. Historic riots erupted after the raid. The anniversary of this cataclysmic moment is now commemorated each year during Gay Pride Week in North America (Gillespie 2008). ${ }^{1}$ During this time, such harassment by police was commonplace in cities like New York, especially harassment resulting from enforcement of anti-sodomy laws (Rosen 1980-81). Further, in the 1960's, the notion that homosexuality was a mental illness prevailed within medical, legal, and social institutions (Gillespie 2008), which contributed to the shame, stigma, and ostracism of the lesbian and gay community (Rosen 1980-81). In his sociological model of mental illness, Scheff (1966) suggests through a theory of residual deviance that being mentally ill is an assigned social role for nonconforming groups. Categorical definitions can be destabilized though because they are socially constructed, thus creating new responses toward the non-normative group in question. In the case of LGBT people, such categorical destabilizations have been evidenced through the American Psychiatric Association's declassification of homosexuality as a mental illness in 1973 (Gillespie 2008), and the redefinition of what constitutes deviant sexual activity

${ }^{1}$ See Armstrong and Crage (2006) for an historical recontexualization of this event. 
with the invalidation of anti-sodomy laws following the 2003 US Supreme Court ruling in Lawrence v. Texas (Carpenter 2012). Police harassment of the LGBT community has declined in recent years, but despite the fact that, for example, Younglove, Kerr, and Vitello (2002) find in one midsize central California city that police did respond appropriately to domestic violence incidents involving same-sex partners, it has not altogether disappeared (Lyons, Jr., DeValve, and Garner 2008).

Acker (2006) argues that structural inequality among workers is produced by the daily activities and practices of organizations that create "inequality regimes" which affect the workplace experiences of employees, their compensation, sense of control, and opportunities. The literature on workplace inequality emphasizes the role that interactions play in creating inequality (e.g., Ridgeway and Correll 2005). Thus, for example, bias on the part of supervisors toward particular groups of workers based on race, gender, or class that results from how the work is organized results in institutionalized and structured inequality. We do not deny the importance of interactions among employees for understanding how structural hierarchies are produced and reproduced. In this paper though, we focus on how the daily activities of the workplace are organized and how the meanings attributed to those activities may influence the attitudes of employees.

We are particularly interested in understanding how the organization of policing may relate to attitudes toward lesbians and gay men. Bernstein, Kostelac, and Gaarder (2003:60) argue that we must look at how "gender and masculinity are embedded in organizational structure" in order to understand the various stakes in sexual inequality that organizational members have by virtue of their locations within that structure. They argue that we must move beyond the narrow understanding of homophobia as the result of psychological factors and to instead advance an understanding of the concept of heterosexism, which they operationalize to take into account structural variables. In the case of policing, for example, they illustrate that civilian employees are less homophobic than sworn officers because they have less stake in maintaining the masculine environment of the workplace (2003).

In this study, we extend this prior work to examine how the organization of daily activities through competing ways of organizing police work and divergent models of justice affects the attitudes of employees toward lesbians and gay men and their civil liberties. While we acknowledge that due to shame and stigma lesbian and gay employees may also harbor negative attitudes toward lesbian and gay people, this study focuses on attitudes of heterosexual employees in order to build on prior research that accounts for the dominant majority's attitudes toward lesbians and gay men and their civil liberties. Because there are different models of policing (e.g., bureaucratic vs. community policing) that structure the daily activities of employees, this study will examine the extent to which the daily practices and activities that structure the police workplace may influence the attitudes of heterosexual employees.

Before examining these structural and contextual variables, however, it is important to look first at the existing research that explains attitudes toward lesbians and gay men and their civil liberties. This research illustrates the importance of demographic factors, religion, and contact with lesbians and gay men for explaining attitudes toward lesbians and gay men and their civil rights. Then we examine specific features of the organization of police work to theorize how they may be related to attitudes toward lesbians and gay men and their civil liberties.

\section{Demographics}

Prior studies on heterosexuals' attitudes toward gay men and lesbians find that older heterosexuals who are male, or less educated hold less favorable attitudes toward gay men than younger heterosexuals who are female, or more educated (Britton 1990; Yang 1999). The few studies that analyze race indicate that African Americans tend to be less tolerant of gay men and lesbians than white Americans (Herek and Capitanio 1996). However, Bernstein et al. (2003) find that African Americans tend to support civil liberties of gay men and lesbians more than whites. Similarly, other studies reveal that although African Americans and whites share similar opinions on issues such as sodomy laws, gay civil liberties, and employment discrimination against gays and lesbians, African Americans are more inclined to support laws that ban antigay discrimination. After controlling for religious and educational differences, African Americans are "moderately more supportive of gay civil liberties and markedly more opposed to antigay employment discrimination" (Lewis 2003). In contrast to prior literature, Bernstein (2004) also found that those who are traditionally married are less supportive of the civil liberties of lesbians and gay men than those in non- 
traditional relationships. Bernstein argues that this may be a function of the increased focus of the lesbian and gay movement's emphasis on same-sex marriage, which may be perceived of as a threat to those who are traditionally married.

\section{Religion}

Previous studies (Yang 1999) find that high levels of religiosity and fundamentalism contributes to more hostility and negative attitudes toward gay men. Bernstein (2004) finds that heterosexuals who attend religious services more often and who literally interpret the Bible are more likely to express antigay attitudes.

\section{Intergroup Contact Theory}

Allport's contact hypothesis predicts that prejudice toward members in a minority group is attenuated when equal status contact takes place between the majority group and minority groups as they seek to achieve common objectives (1954). Testing this hypothesis, a number of studies have found that the extent of interpersonal contact is one of the most significant correlates in helping to explain heterosexuals' attitudes toward gay men and lesbians (e.g., Herek and Glunt 1993). Consistent with the contact hypothesis, Lyons et al. (2008) found in a survey of $95 \%$ of all police chiefs in Texas that the more contact they had with gay people the more they accepted them and the more they rejected gay stereotypes. On the other hand, the less contact police chiefs had with gay people the more inclined they would (hypothetically speaking) be to quit their job if they had to work alongside a gay person.

Thus based on prior research, we expect that education, being female, and being in non-traditional relationships (cohabiting, divorced or single) will increase levels of tolerance for lesbians and gay men and their civil rights. Race will either have no effect or whites will be less tolerant of lesbians and gay men than people of color. In addition, lower levels of religiosity and religious fundamentalism will also reduce intolerance. Finally, increased contact with lesbians and gay men should increase tolerance.

\section{Inequality Regimes and the Structure of Policing}

While the factors derived from the extant literature tell us much about the sources of homophobia and heterosexism, in this section, we seek to build on this existing literature, as it pertains specifically to law enforcement agencies. To do so, we examine the shift toward community policing and civilianization and then hypothesize the relationship between community policing and attitudes toward lesbians and gay men and their civil liberties.

In 1994, the Violent Crime Control and Law Enforcement Act sought to implement community policing models in US law enforcement agencies nationwide. Departments that adopt such models undergo a re-missioning. Although they remain structured and hierarchical, it is the relationship between police agencies and the community that is reshaped when such models are implemented. With that said, community policing is a more bi-directional approach to communicating between police and citizens instead of the top-down, uni-directional approach found in bureaucratic policing. Police engaging in this form of policing become involved in community groups and foster communication among residents to encourage community responsibility and ensure neighborhood safety (Manning 1984). Community policing approaches also emphasize more "feminine" traits, especially compared to traditional policing approaches, which tend to reward "tough, aggressive, even violent behavior" (Los Angeles 2000). Traditional policing is impersonal and police and public relations are hierarchical, detached, authoritative, and centrally managed. While it is true that commonly accepted portrayals depicting police culture tend to obscure variation in outlooks among officers (Paoline, Myers, and Worden 2000), the criminal justice system, by and large though, remains dominated by hypermasculinity. Further, it reflects a culture that is white and that promotes norms of "compulsory heterosexuality" and disdain of homosexuality (Messerschmidt 1993). Therefore, we expect that attitudes toward community policing and attitudes toward lesbians and gay men and their civil liberties will be related.

This shift from traditional to community-oriented policing has been paralleled by the process of civilianization of police departments. Civilianization refers to a police department's hiring of "nonsworn personnel to replace or augment its corps of sworn officers, typically with the aims of reducing costs and improving service" (Forst 2000: 23). Civilianization has expanded considerably in the last 50 years (Kostelac 2008) and, unlike the police, the majority of civilian employees are female (U.S. DOJ, 2012). Civilian employees are hired to fill a variety of positions to relieve officers from supportive services, so that they can focus on primary policing duties (Forst 2000). 
Increasingly, civilian employees are also being hired to fulfill duties closer to that of law enforcement and now even occupy some of the highest positions within police departments (Kostelac 2008). Civilianization is viewed as integral to implementing community policing models, because it facilitates bringing agencies into more intimate contact with the communities they serve, while enabling sworn officers to focus on core police duties rooted in community policing philosophies (e.g., community safety, quality of life concerns) (King 1999). These shifts have implications for the culture and workplace of the police.

A number of studies have considered attitudes and perceptions that the public have of police, policing practices, and community-policing approaches (e.g., Reisig and Parks 2000) and of the attitudes held by police officers toward community policing (Novak, Alarid, and Lucas 2003; Pelfrey 2004). Brooks, Piquero, and Cronin (1993) find that a link exists between police officers' positive attitudes toward community members and their acceptance of community policing approaches.

Attitudes toward community policing and attitudes toward women appear to be related as well. DeLong (1997) finds in her study of police perceptions of community policing and female officers that police from a community-policing department viewed community policing approaches and female officers more positively than officers from a traditional department.

Community policing is also linked to rehabilitative models of justice, employing mediation, reintegration, and other forms of local justice, rather than punitive models. $^{2} \quad$ For example, Guarino-Ghezzi (1994) examines reintegrative surveillance, which combines community policing and community-based corrections, by looking at the role police officers play in linking juvenile offenders to social supports in place of a more punitive approach. Meanwhile, Unnever, Cullen, and Jones find that people who manifested more racial resentment were also more likely to support a punitive approach to fighting crime by "arresting, convicting, and incarcerating criminal offenders" than those who held

\footnotetext{
'The rehabilitative approach to punishment known as the "rehabilitative ideal" was dominant in the early $20^{\text {th }}$ century, but was considered a failure and abandoned by the 1970s. Rehabilitation though still remains a goal of the criminal justice system. Rehabilitative approaches to punishment have historically been employed through a second stage of social control after police intervention and have enjoyed a recent revival through "therapeutic" courts (Gabbay 2005:390). At the same time though, community policing approaches to crime control do contain elements of rehabilitation such as restorative justice models like victim-offender mediation (Nicholl 1999).
}

"egalitarian" beliefs (2008: 24-25). Thus not only do we expect attitudes toward community policing and lesbians and gay men to be related, but we expect attitudes toward punishment, whether rehabilitative or punitive, to be related as well.

To examine the relationship between community policing and approaches to rehabilitation on the one hand and to lesbians and gay men and their civil rights on the other, we posit the following hypotheses:

\section{Community Policing}

The more heterosexual sworn officers and civilian employees support adopting community policing models within their department, the more tolerant their attitudes will be toward gay men and lesbians $(\mathrm{H} 1 \mathrm{a})$, the more they will support civil liberties of gay men and lesbians $(\mathrm{H} 1 \mathrm{~b})$, and the less likely they are to accept negative stereotypes of lesbians and gay men or to believe that lesbians and gay men would make inferior police officers $(\mathrm{H} 1 \mathrm{c})$.

\section{Rehabilitation}

The more heterosexual sworn officers and civilian employees support the rehabilitation of offenders, the more tolerant their attitudes will be toward gay men and lesbians $(\mathrm{H} 1 \mathrm{~d})$, the more they will support civil liberties of gay men and lesbians $(\mathrm{H} 1 \mathrm{e})$, and the less likely they are to accept negative stereotypes of lesbians and gay men or to believe that lesbians and gay men would make inferior police officers $(\mathrm{H} 1 \mathrm{f})$.

\section{METHODS}

The results from this study are based on a 1999 Workplace Environment Survey of the Saguaro Police Department (a pseudonym for a medium-size law enforcement agency located in the southwestern United States), which was designed to analyze myriad factors that affect police officers' job experiences. The study yielded a sample size of 249 sworn officers and 144 civilian employees (see Bernstein and Kostelac 2002, for more specifics about the survey and its distribution) and had a response rate of $33 \%$. Saguaro is located in an extremely conservative state that, at the time the survey was conducted, granted no statewide employment protection for LGBT people and still criminalized private consensual sodomy between adults. The city in which Saguaro is located is a more liberal city within the state.

To date, few surveys of police attitudes concern sensitive issues. In their study exploring police sexual 
violence against women, Kraska and Kappeler (1995) contend that, "The difficulty of acquiring knowledge on this sensitive topic cannot be overstated. The wall of secrecy in policing, which conceals these crimes ('the blue wall of silence'), forms a difficult barrier for the researcher" (p. 91; see also Manning 1995). Police officers will even go as far as lying under oath in court to protect fellow officers accused of misconduct (Chin and Wells 1998).

In light of this seemingly impenetrable wall of secrecy, it is not surprising that Bernstein and Kostelac (2002) found that only $1.6 \%$ of police surveys over a 21 year period focused on sensitive topics where police officers, instead of departments, served as the units of analysis, where the study relied on primary survey data, and was carried out in the United States. The difficulty of eliciting responses on sensitive issues is not unique to police culture though. For example, the U.S. Department of Defense's (DoD) 2010 survey of military personnel's views on Don't Ask, Don't Tell garnered a response rate of $28 \%$, which they consider "average for the U.S. military" (p. 3). Thus, the response rate of the Workplace Environment Survey has an above average sample size when compared to other studies on sensitive topics, providing a rare opportunity to examine police attitudes toward gay men and lesbians.

Another potential criticism of using the Workplace Environment Survey is that the survey was administered in 1999. Since that time the country has undergone profound cultural shifts with respect to views on homosexuality, as evidenced by the overturning of a key section of the federal Defense of Marriage Act by the U.S. Supreme Court in 2013 (U.S. v. Windsor) and the repeal of Don't Ask, Don't Tell in 2011. While the repeal of Don't Ask, Don't Tell applies to civil liberties within the military, the landmark U.S. Supreme Court ruling of Lawrence v. Texas in 2003 applies to civil liberties within the public sphere. This ruling decriminalized consensual sexual behavior between same-sex individuals nationally. Codefendants Lawrence and Garner were arrested in 1998 for allegedly engaging in homosexual acts, which were illegal, at the time, under Texas law. In a detailed examination of the case, Carpenter (2012) discusses how the homophobic attitudes of police was a major factor influencing the decision to arrest the codefendants. After being called to the scene in what ended up being a false report of a weapons disturbance, local police turned their attention to the sexual orientation of the co-defendants, making demeaning and homophobic remarks (p. 76) before arresting the co-defendants for male homosexuality and engaging in "deviate sexual intercourse," which the arresting officer found personally offensive (pp. 79-81). In the years since the survey was administered, progressive social change has also taken place within the prison system. Despite the fact that prison wardens generally do not believe a substantial level of sexual activity (i.e., consensual, coercive, and/or violent) takes place inside their facilities even though previous research has established that it does (Hensley and Tewksbury 2005: 194), the Prison Rape Elimination Act (PREA) of 2003 and its standards for federal prisons, which became legally binding in 2012, reflect increased public policy efforts to alter the institutional culture and organizational form in order to advance the rights and address the maltreatment of LGBT citizens. PREA and Lawrence $v$. Texas mark important policy and legal changes that have influenced debate on this shifting relationship between agents of social control and LGBT citizens.

Thus, in light of these profound cultural shifts, one would expect heterosexual police officers to be much more tolerant now of gay men and lesbians than they were 15 years ago. The objective of this study though is not to measure tolerance levels of gay men and lesbians per se. If it were, we would then, of course, need a more current data set. Instead, our objective is to make a theoretical contribution and generate hypotheses about whether the structure of a police department, and workplaces in general, affect the attitudes of workers and to test such hypotheses using empirical data. Therefore, the hypotheses supported by the empirical data should hold over time. For example, hypothesis $1 \mathrm{~b}$ expects that the more heterosexual sworn officers and civilian employees support adopting community policing models within their department the more they will support the civil liberties of gay men and lesbians. This expectation should hold over time and provide illustrative evidence about the relationship between workplace practices and employee attitudes.

\section{DEPENDENT VARIABLES}

We have three different dependent variables, each of which captures different dimensions of attitudes toward lesbians and gay men and their civil liberties (see Table 1 for descriptive statistics on all variables used). First, to measure the dependent variable of homophobia, the current study uses Herek's Attitudes Toward Gay Men and Lesbians (ATGL) scale, which has been shown to maintain validity and reliability in numerous research environments (Herek and Glunt 
Table 1: Descriptive Statistics for Variables Used in the Analysis

\begin{tabular}{|c|c|c|c|c|c|}
\hline Variable & Description & Metric & \multicolumn{3}{|c|}{$\begin{array}{c}\text { Heterosexual } \\
\text { Sworn Officers \& } \\
\text { Civilian } \\
\text { Employees }\end{array}$} \\
\hline \multicolumn{6}{|l|}{ Dependent Variables } \\
\hline \multicolumn{6}{|l|}{ Attitudes } \\
\hline \multirow[t]{3}{*}{$\begin{array}{l}\text { Cronbach's Alpha for } \\
\text { Sworn Officers \& Civilian } \\
\text { Employees: } 0.893\end{array}$} & (2) I think male homosexuals are disgusting [reverse coded] & $\begin{array}{l}5=\text { strongly } \\
\text { disagree }\end{array}$ & & & \\
\hline & $\begin{array}{l}\text { (3) Male homosexuality is a natural expression of sexuality between } \\
\text { men }\end{array}$ & & & & \\
\hline & $\begin{array}{c}\text { (6) Female homosexuality is a natural expression of sexuality between } \\
\text { women }\end{array}$ & & & & \\
\hline \multicolumn{6}{|l|}{ Civil Liberties } \\
\hline Scale: Civil Liberties & (1) Homosexuals should be allowed to teach in colleges & $\begin{array}{l}1=\text { strongly } \\
\text { agree to }\end{array}$ & 2 & 0.89 & 354 \\
\hline \multirow[t]{2}{*}{$\begin{array}{l}\text { Cronbach's Alpha for } \\
\text { Sworn Officers \& Civilian } \\
\text { Employees: } 0.841\end{array}$} & (2) Homosexuals should be allowed to speak in public & $\begin{array}{l}5=\text { strongly } \\
\text { disagree }\end{array}$ & & & \\
\hline & (3) It is okay for books about homosexuals to be in libraries & & & & \\
\hline & & $4=46$ or older & & & \\
\hline Sex & Sex is male & $\begin{array}{l}0=\text { Female; } \\
1=\text { Male }\end{array}$ & 0.593 & 0.49 & 356 \\
\hline Race & Race of respondent-white & $\begin{array}{l}0=\text { Non-White; } \\
\text { 1=White }\end{array}$ & 0.79 & 0.41 & 351 \\
\hline \multirow[t]{2}{*}{ Education } & Level of Education Attained & $\begin{array}{l}1=\text { less than } \\
12 \text { th grade }\end{array}$ & 3.48 & 0.88 & 358 \\
\hline & & $\begin{array}{l}\text { to } 6=\text { post- } \\
\text { graduate } \\
\text { degree }\end{array}$ & & & \\
\hline Employee Status & Employee status is civilian employee & $\begin{array}{l}0 \text { Sworn } \\
\text { Officers; } 1 \\
\text { Civilan } \\
\text { Employees }\end{array}$ & 0.38 & 0.49 & 358 \\
\hline \multicolumn{6}{|l|}{ Religion } \\
\hline Attendance & How often do you attend religious services? & $\begin{array}{c}\text { 1=Never/Less } \\
\text { than once a } \\
\text { year }\end{array}$ & 2.99 & 1.95 & 342 \\
\hline & & $\begin{array}{l}\text { to } 6=\text { Once a } \\
\text { week or more }\end{array}$ & & & \\
\hline
\end{tabular}


(Table 1). Continued.

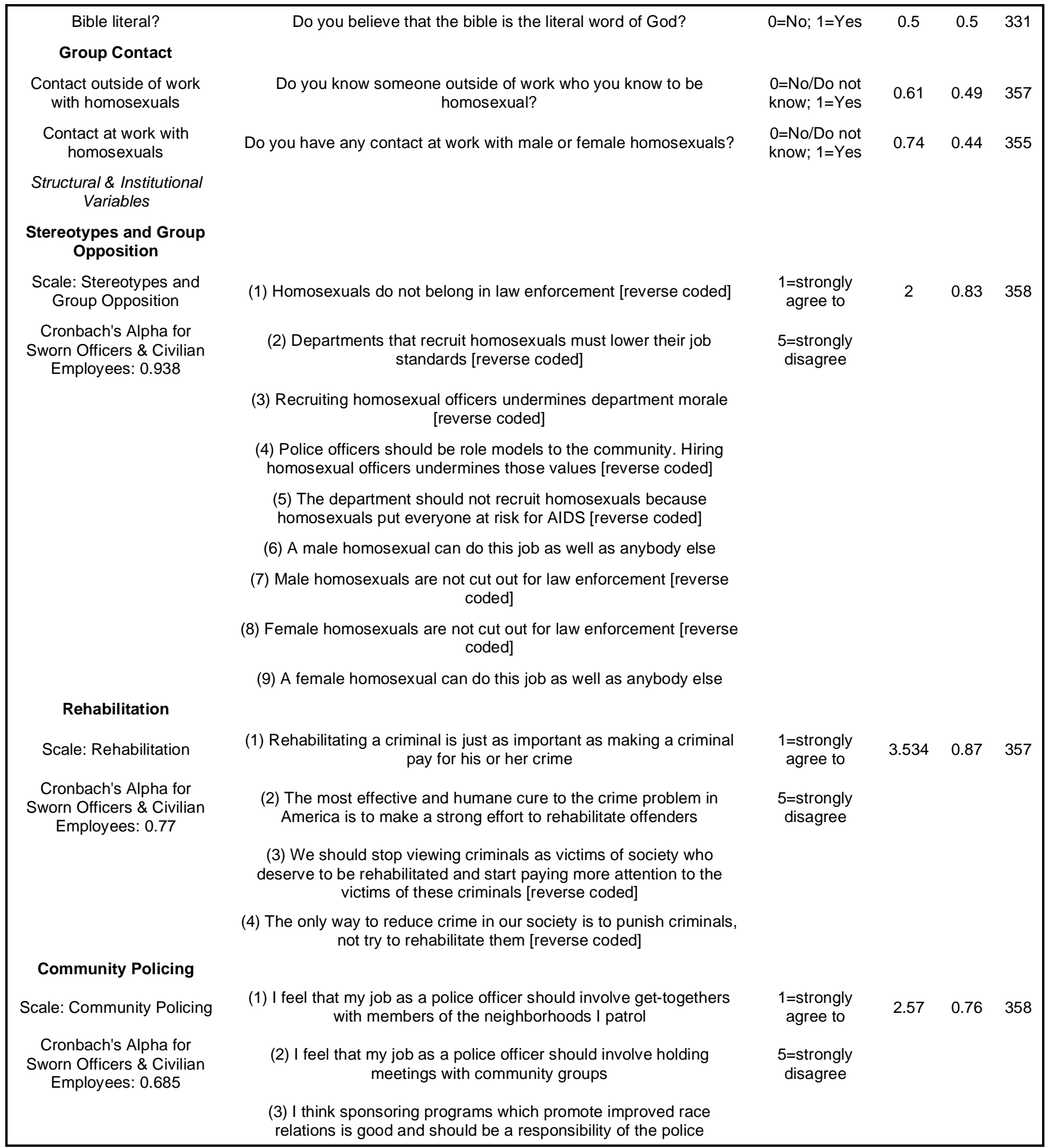

1993). Table 1 shows the six items that comprise both the attitudes toward gay men (ATG) and attitudes toward lesbian (ATL) subscales. Each subscale asks respondents whether they view homosexuality as "wrong," "disgusting," or as a "natural expression of sexuality between (men/women)," separately. Reliability analysis showed that ATGL formed a coherent scale for all respondents $(\alpha=0.893)$. ATGL can be understood as an affective measure of homophobia that captures a visceral aversion to homosexuality.

The second dependent variable measures respondents' support for civil liberties of gay men and lesbians by employing a three-item scale taken from 
the General Social Survey (GSS) (see Table 1). Although the authors prefer the use of the terms gay and lesbian over the term homosexual due to its many negative connotations, in keeping with the language of the GSS, respondents are asked whether "homosexuals" should be allowed to teach in colleges, speak in public, and whether it is okay for books about homosexuals to be in libraries (scale $\alpha=0.841$ ). This dependent variable differs from ATGL because it is a measure of support for civil rights and does not necessarily relate to affective feelings toward lesbians and gay men.

The third dependent variable measures acceptance of negative stereotypes about lesbians and gay men and respondents' sense of heterosexual group superiority ("group position," Blumer 1958a, 1958b; Bernstein 2004) by employing a nine-item scale. Five survey questions ask respondents whether they accept different negative stereotypes about lesbians and gay men. Specifically, they ask whether homosexuals belong in law enforcement, whether departmental hiring of homosexuals lowers job standards, or recruiting homosexual officers undermines department morale. The survey also asks whether homosexual police officers can serve as good role models within the community, and whether recruiting homosexuals puts other officers at risk for AIDS. Meanwhile, four survey questions measuring group position are asked to determine whether respondents believe male and female homosexuals are cut out for law enforcement and can do this job just as well as anybody. Reliability analysis showed that the stereotypes and group position scale formed a coherent scale for all respondents $(\alpha=0.938)$. This measure, like ATGL, contains an affective, emotional dimension linked to feelings about lesbians and gay men. The variables comprising the three dependent variable scales are measured on a 5-point Likert-type scale from "strongly agree" to "strongly disagree." The three scales are coded so that higher scores indicate less tolerance of gay men and lesbians on these various dimensions.

\section{INDEPENDENT VARIABLES}

To measure demographics, we include age, education, and dummy variables for sex (male or female [as the reference category]), race (white or nonwhite [as the reference category]), employee status (sworn officer or civilian employee [as the reference category], and traditionally married (yesmarried/widowed or single/divorced/separated/living with a partner [as the reference category]). To measure religiosity, we use how often respondents attend religious services and whether they literally interpret the Bible (yes or no [as the reference category]).

Contact outside of work and at work with gay men and lesbians was measured using the questions, "Do you know someone outside of work who you know to be homosexual?" and "Do you have any contact with male or female homosexuals?" A dummy variable was created for both questions (yes or no [as the reference category]).

In order to measure attitudes toward rehabilitation we created a four-item scale. The four survey questions ask respondents whether rehabilitating a criminal is just as important as punishing the criminal for his or her crime, and whether the most effective way to address the crime problem in America is to make a strong effort to rehabilitate offenders. The survey also asks whether we should start focusing more on the victims of these criminals instead of viewing criminals as victims of society in need of rehabilitation, and whether the only way to reduce crime in our society is to punish criminals. Reliability analysis showed that the rehabilitation scale formed a coherent scale for all respondents $(\alpha=0.77)$. Rehabilitation is measured on a 5-point Likert-type scale from "strongly agree" to "strongly disagree," and the scale is coded so that higher scores indicate less support for rehabilitation.

To measure support for community policing we created a three-item scale. The three questions ask respondents whether they agree that police officers should participate in get-togethers with members of the communities they patrol, meet with community groups, and sponsor programs that promote better race relations. Reliability analysis showed that the community policing scale formed a coherent scale for all respondents $(\alpha=0.685)$. Community policing is also measured on a 5-point Likert-type scale from "strongly agree" to "strongly disagree," and the scale is coded so that higher scores indicate less support for community policing approaches.

To carry out this analysis, statistics were computed using SPSS 15.0. Table 2 presents the zero-order correlations among the variables used.

\section{RESULTS}

We constructed nine models using selected independent measures for predicting ATGL, support for 


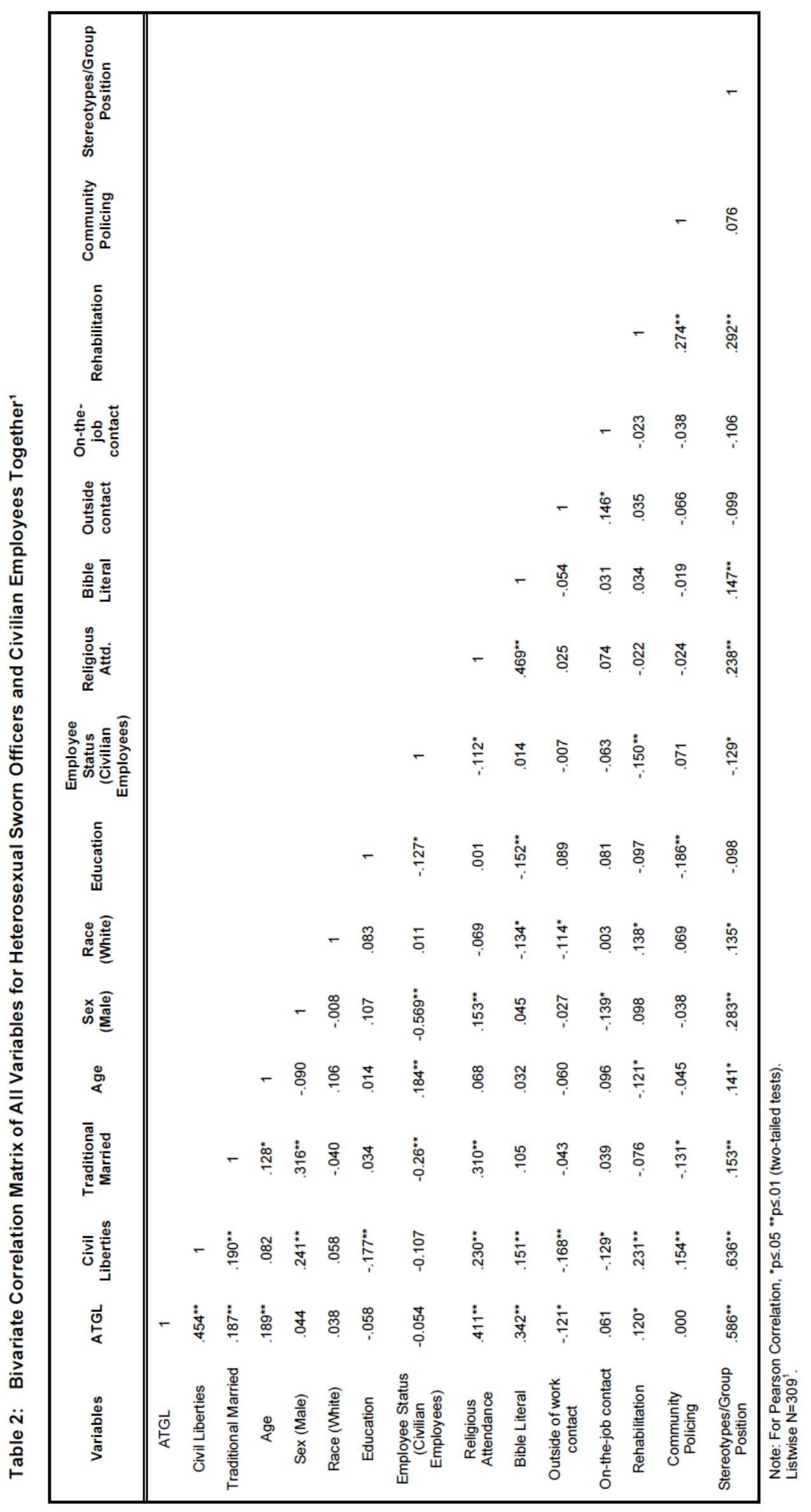




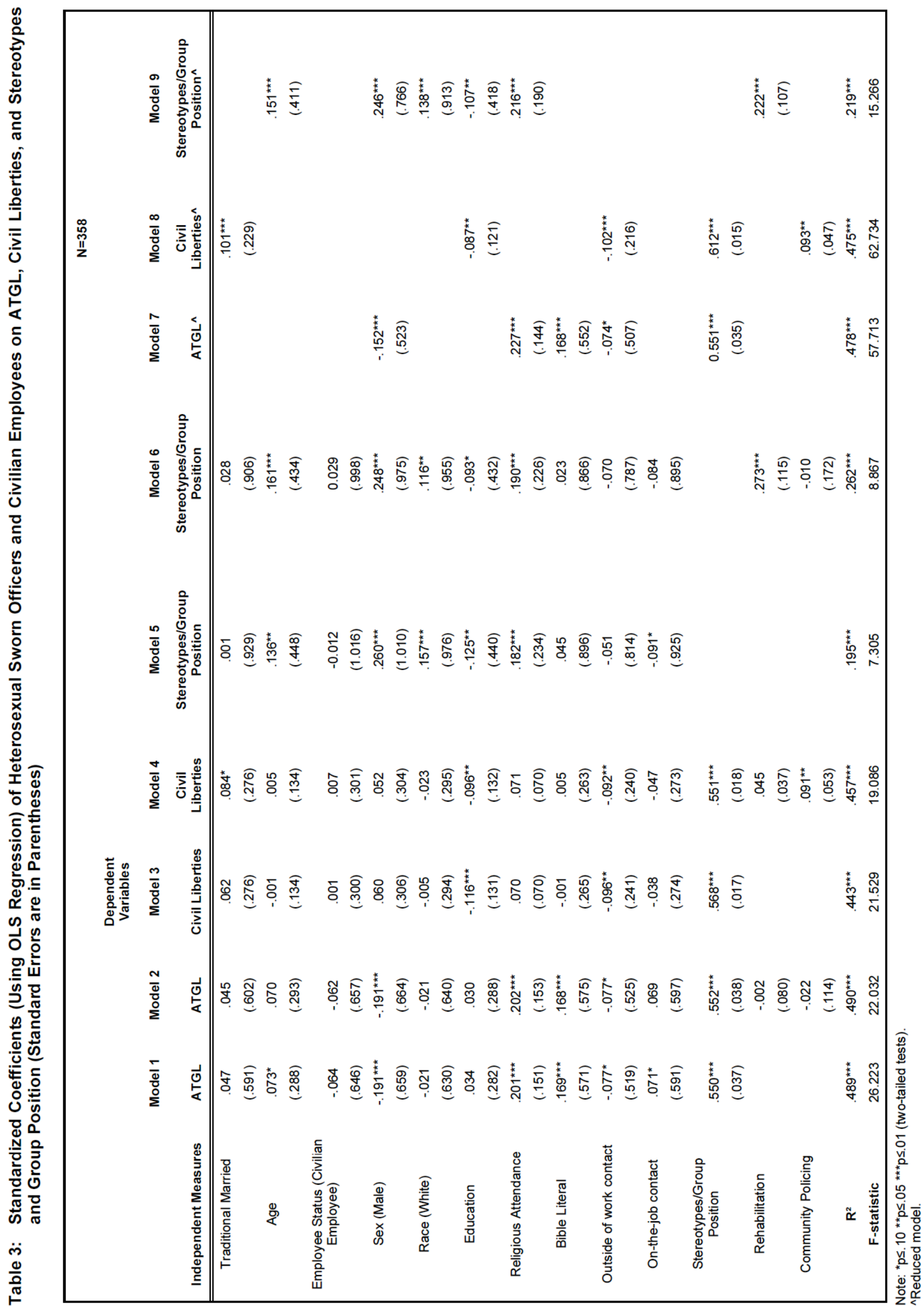


civil liberties, and views on stereotypes/group position. Table 3 presents the results of the OLS regression (the standardized regression coefficients and standard errors). All reported significance tests are two-tailed. Listwise deletion was employed to deal with missing data. For each dependent variable (see Models 1-6, Table 3), we first examine the variables shown to be significant in prior research. Then we introduce our community policing and rehabilitation scales. Models 79 present the reduced models, which include only those independent variables that were significant at the $p \leq .10$ level in the full models.

For Model 1, the independent variables age, religious attendance, literal interpretation of the Bible, outside-of-work contact, on-the-job contact, and stereotypes/group position all significantly influence homophobia in the expected direction; however, the findings are weakly significant for age $(B=.073, p<$ $.10)$, on-the-job contact ( $B=.071, p<.10)$, and outside-of-work contact $(B=-.077, p<.10)$. Consistent with prior findings, stereotypes/group position has the strongest impact on homophobia (Bernstein 2004) followed by religious attendance and literal interpretation of the Bible.

Model 2 incorporates measures of rehabilitation and community policing-neither of which significantly influences homophobia, contradicting hypotheses $1 \mathrm{a}$ and 1d. Stereotypes/group position still has the strongest affect on homophobia followed by religious attendance and literal interpretation of the Bible, while age and on-the-job contact no longer remain significant. Outside-of-work contact though remains weakly significant. The only counterintuitive finding in Models 1 and 2 (and Model 7, the reduced ATGL model) is for sex. Since the coefficient is negative, it suggests that females are significantly more homophobic than males. However, after running a ttest, heterosexual men were significantly more intolerant on ATG at the .001 level $(M=3.33, S D=$ 1.04) than heterosexual women $(M=2.96, S D=1.01)$, while there was no statistically significant difference found between both sexes on ATL, which replicates findings of previous studies. Further, Bernstein (2004) found in her work uncovering paths to homophobia, that the net effect of sex became essentially nonexistent, which is consistent with the non-significant zero-order correlation between sex and ATGL (see Table 2). Following Bernstein, our findings also suggest that "sex differences in homophobia are an artifact of feelings of group superiority and acceptance of stereotypes" (2004: 49). Together, these variables explain $49 \%$ of the variance in ATGL.

In Model 3, consistent with the literature, we find that higher levels of education, outside of work contact, and less acceptance of negative stereotypes/group position increase support for civil liberties. In Model 4, after adding the variables rehabilitation and community policing, traditionally married becomes weakly significant, while education, outside of work contact, and stereotypes/group position remain strongly significant as expected. Further, while rehabilitation is not significant, community policing is quite significant ( $B$ $=.091, p \leq .05$ ) in its affect on civil liberties, with higher levels of support for community policing leading to higher levels of support for civil liberties. In fact, the impact of community policing is only marginally smaller than the impact of education and outside of work contact in influencing support for civil liberties. Thus we find support for $\mathrm{H} 1 \mathrm{~b}$ and no direct support for $\mathrm{H} 1 \mathrm{e}$.

In Model 5, age, sex, race, education, and religious attendance all significantly influence stereotypes/group position in the expected direction, while on-the-job contact is weakly significant. In Model 6, adding the variables rehabilitation and community policing adds significantly to the total amount of variance explained by Model 5 , increasing it by $6.7 \%$. Meanwhile, age, sex, race, and religious attendance remain very significant in the expected direction in Model 6, while education becomes weakly significant in the expected direction. Although community policing is not significant, rehabilitation strongly influences stereotypes/ group position in the expected direction $(B=.273, p \leq$ .01 ), with higher levels of support for rehabilitation leading to lower agreement with negative stereotypes/ group position. Given that stereotypes/group position is the strongest predictor of both ATGL and support for civil liberties, rehabilitation influences ATGL and civil liberties indirectly while community policing also influences civil liberties directly. Thus we find support for $\mathrm{H} 1 \mathrm{f}$ and indirect support for $\mathrm{H} 1 \mathrm{~d}$ and $\mathrm{H} 1 \mathrm{e}$.

In Model 7, the reduced model for ATGL, the variables religious attendance, literal interpretation of the Bible, and stereotypes/group position still significantly influence ATGL in the expected direction, while outside of work contact remains weakly significant. In Model 8, the reduced model for civil liberties, the variables traditionally married, education, outside of work contact, and stereotypes/group position still significantly influence civil liberties in the expected direction. The community-policing variable also 
remains significant $(B=.093, p \leq .05)$, supporting Hypothesis 1b.

In Model 9, the reduced model for stereotypes/ group position, the variables age, sex, race, and religious attendance remain significant in the expected direction, while education becomes stronger in the expected direction than in the full model. The variable rehabilitation remains significant in its impact on stereotypes/group position in the expected direction ( $B$ $=.222, p \leq .01$ ). As previously noted, the intermediate variables stereotypes/group position have been found to have the strongest influence on ATGL (Bernstein 2004). Although rehabilitation does not directly influence ATGL, it influences it indirectly through the stereotypes/group position variable, supporting Hypothesis 1d.

In sum, we find that support for community policing does not affect either ATGL or acceptance of negative stereotypes/group position directly. However we do find that support for community policing influences support for the civil liberties of lesbians and gay men. Furthermore, we find that rehabilitation has a direct impact on stereotypes/group position and an indirect impact on ATGL and civil liberties.

\section{DISCUSSION AND CONCLUSION}

Many studies illustrate how the organization of the workplace and, in particular, interactions among workers can create and perpetuate inequality regimes that reproduce gender inequality and inequality based on sexual orientation (Acker 2006). In this study, we have examined how re-organizing the tasks of the workplace and the meaning of the work could potentially lead to greater tolerance for lesbians and gay men and support for their civil rights. Policing has traditionally been a masculinist workplace that has been historically hostile to gay men and lesbians. This paper has examined how recent changes in the structure of policing as an occupation, namely the move toward community policing and increasing civilianization, may influence the attitudes of police department employees toward lesbians and gay men and their civil rights.

While support for community policing did not influence general affective attitudes toward lesbians and gay men as measured by the ATGL scale or acceptance of negative stereotypes/group position directly, we found that support for community policing is directly related to increased support for the civil liberties of lesbians and gay men. Given that ATGL is an affective measure of aversion to lesbians and gay men, it makes sense that community policing would influence civil liberties, but not ATGL or stereotypes. Additional research using qualitative methods should elucidate this distinction by examining why support for community policing is related to increased levels of support for the civil liberties of lesbians and gay men but does not influence ATGL. Moreover, this finding has implications for police academy pedagogy and continuing education for police. We recommend that police training curriculum on community policing first and foremost seek to combat homophobia. We also recommend that police trainings communicate to officers who may not agree with the so-called gay and lesbian "lifestyle" for religious or other personal reasons, that the two are not mutually exclusive: that they can still fulfill community policing duties by upholding the civil liberties of lesbians and gay men without personally endorsing a way of life that they may dislike.

In addition, we have found that support for rehabilitation is the second strongest factor influencing acceptance of anti-gay/lesbian stereotypes and a sense of heterosexual group superiority. Although support for rehabilitative models of justice does not directly affect ATGL, support for rehabilitation indirectly influences ATGL through its influence on stereotypes/ group position. This is in line with Johnson's research findings on the black and white divide in punitive attitudes. She finds that racial prejudice helps account for why whites support punitive criminal justice policies (2008). The rehabilitation measure is also likely linked to acceptance of negative stereotypes about offenders, such as being inherently "bad" or beyond redemption. Thus it follows that those who oppose rehabilitation would also be accepting of negative stereotypes/group position, which indirectly influences civil liberties and ATGL. Future studies should further explore the nexus between rehabilitation and its indirect influence on civil liberties and ATGL. What these overall findings suggest is that in police departments that adopt community policing models and promote rehabilitative models of justice, employees may be or become more supportive of lesbians and gay men and their civil liberties. These findings support previous research suggesting that support for community policing is associated with greater support for female police officers and gender equality (Sims et al. 2003). Similar relationships hold with regard to ethnic and racial minorities (Harpaz and Herzog 2013). 
Certainly, some limitations are evident in this present study. First, because our data is crosssectional, we cannot say whether or not the shift toward community policing actually changes employees' attitudes toward community policing. It is possible that changing to community policing models may not alter the attitudes of employees who dislike that approach. In fact, "reform" training (i.e., training in order to alter beliefs and attitudes) faces considerable challenges because beliefs and attitudes regarding policing approaches are fairly stable cognitive states, and although they are not impossible to alter, they are very hard to change (Buerger 1998). Yet, in her study examining the affect of basic training on shaping police recruits' attitudes and beliefs about community policing, Haarr (1997) finds that basic training has a positive affect on shaping recruits' attitudes and beliefs toward community policing. Over time though, she finds that these positive changes in attitudes diminish once recruits enter field training and are immersed in the organizational culture and work environment at their assigned police agencies. Haarr posits that sustaining positive attitudinal changes achieved in basic training necessitates reinforcement of community policing practices within police recruits' newly assigned police agencies (2001). When leaders practice community policing, we can expect that it will increase the likelihood that police recruits assigned to such agencies will continue to maintain positive attitudes and beliefs that support community policing (Mastrofski and Ritti 1996). Thus, we think that it is more likely that departments that adopt and successfully implement community policing models are likely to change the attitudes of their employees, socialize new employees into supporting these models of policing, and that those employees who strongly dislike such approaches might leave of their own accord. If this is the case, then reorganizing the daily practices of the police will alter the attitudes of employees toward community policing which may in turn make them more tolerant of lesbians and gay men and possibly of other minority groups as well. Research that compares attitudes across different types of departments (e.g., those with community policing approaches and those with bureaucratic approaches) and differentiated environments (e.g., urban vs. rural settings, settings with more vs. less LGBT rights), as well as longitudinal research designed to measure changes in attitudes over time is needed. Doing so will enable us to more fully explore these questions and generate studies of comparison and falsifiability to our primary claims and hypotheses, while helping to differentiate the effects of implementing community policing models from broader social trends toward lesbian and gay equality.

Second, multisite data across different types of departments is also needed to address the question of generalizability with regard to the findings in the present study. Our findings are based only on the attitudes of officers and civilian employees from a single police department and from one geographical site and are, therefore, not representative of police officers' attitudes nationwide. Third, police officers that filled out the survey may not have been entirely honest in their responses and may have suppressed their real views on these sensitive issues. However, because the survey was administered in a way that ensured anonymity and completed on a voluntary basis, the possibility that social desirability bias influenced the survey results are low.

Our findings suggest that the daily practices that structure the workplace are related to and can potentially influence the attitudes of employees. Thus for employers concerned with fostering a diverse and equitable work environment, more attention should be paid to how the work of the organization is carried out. While diversity training may be important in fostering acceptance of people different from oneself, more attention should be paid to how work is organized, the skill sets involved, the relations that are fostered among different groups, and the gendered meaning of the work.

\section{REFERENCES}

Acker, Joan. 2006. "Inequality Regimes: Gender, Class, and Race in Organizations." Gender \& Society 20(4):441-64. http://dx.doi.org/10.1177/0891243206289499

Adam, Barry D. 1998. "Theorizing Homophobia." Sexualities 1:387404. http://dx.doi.org/10.1177/136346098001004001

Allport, Gordon. 1954. The Nature of Prejudice, New York: AddisonWesley.

Armstrong, Elizabeth A. and Suzanna M. Crage. 2006. "Movements and Memory: The Making of the Stonewall Myth." American Sociological Review 71: 724-51. http://dx.doi.org/10.1177/000312240607100502

Bernstein, Mary. 2004. "Paths to Homophobia." Sexuality Research and Social Policy 1:41-55. http://dx.doi.org/10.1525/srsp.2004.1.2.41

Bernstein, Mary and Constance Kostelac. 2002. "Lavender and Blue Attitudes about Homosexuality and Behavior toward Lesbians and Gay Men among Police Officers." Journal of Contemporary Criminal Justice 18:302-28. http://dx.doi.org/10.1177/1043986202018003006

Bernstein, Mary, Constance Kostelac, and Emily Gaarder. 2003. 'Understanding 'Heterosexism:' Applying Theories of Racial Prejudice to Homophobia Using Data from a Southwestern Police Department." Race, Gender \& Class 10(4):54-74. 
Blumer, Herbert. 1958a. "Race Prejudice as a Sense of Group Position." Pacific Sociological Review 1:3-7. http://dx.doi.org/10.2307/1388607

Blumer, Herbert. 1958b. "Recent Research on Race Relations: United States of America." International Social Science Bulletin 10:403-77.

Bolton, Kenneth Jr. 2003. "Shared Perceptions: Black Officers Discuss Continuing Barriers to Policing." Policing: An International Journal of Policing Strategies \& Management 26:386-99.

http://dx.doi.org/10.1108/13639510310489458

Britton, Dana M. 1990. "Homophobia and Homosociality: An Analysis of Boundary Maintenance." The Sociological Quarterly 31: 423-39.

http://dx.doi.org/10.1111/j.1533-8525.1990.tb00337.x

Brooks, Laure W., Alex Piquero, and James Cronin. 1993. "Police Officer Attitudes Concerning Their Communities and Their Roles: A Comparison of Two Suburban Police Departments." American Journal of Police 12(3):115-39.

Buerger, M.E. 1998. "Police Training as a Pentecost: Using Tools Singularly III-Suited to the Purpose of Reform." Police Quarterly 1:27-63.

Carpenter, Dale. 2012. Flagrant Conduct: The Story of Lawrence v. Texas. New York: W.W. Norton \& Company.

Chin, Gabriel J. and Scott Wells. 1998. 'The 'Blue Wall of Silence' as Evidence of Bias and Motive to Lie: A New Approach to Police Perjury." University of Pittsburgh Law Review 59:23399.

Colvin, Roddrick A. 2012. Gay and Lesbian Cops: Diversity and Effective Policing. Boulder, CO: Lynne Rienner Publishers, Inc.

DeLong, R.K. 1997. "An Analysis of Police Perceptions of Community Policing and Female Officers." PhD dissertation, Western Michigan University, Kalamazoo.

Elias, Norbert. 2000. The Civilizing Process: Sociogenetic and Psychogenetic Investigations. Revised Edition. Oxford: Blackwell.

Fligstein, Neil and Doug McAdam. 2011. "Toward a General Theory of Strategic Action Fields." Sociological Theory 29(1):1-26. http://dx.doi.org/10.1111/j.1467-9558.2010.01385.x

Forst, Brian. 2000. "The Privatization and Civilianization of Policing." Boundary Changes in Criminal Justices Organizations, Criminal Justice: Vol. 2, pp. 19-79.

Gabbay, Zvi D. 2005. "Justifying Restorative Justice: A Theoretical Justification for the Use of Restorative Justice Practices." Journal of Dispute Resolution 2:349-97.

Gillespie, Wayne. 2008. "Thirty-Five Years After Stonewall: An Exploratory Study of Satisfaction with Police among Gay, Lesbian, and Bisexual Persons at the $34^{\text {th }}$ Annual Atlanta Pride Festival." Journal of Homosexuality 55(4):619-47. http://dx.doi.org/10.1080/00918360802421759

Guarino-Ghezzi, Susan. 1994. "Reintegrative Police Surveillance of Juvenile Offenders: Forging an Urban Model." Crime and Delinquency 40(2):131-53. http://dx.doi.org/10.1177/0011128794040002001

Haarr, Robin N. 1997. "Patterns of Interaction in a Police Patrol Bureau: Race and Gender Barriers to Integration." Justice Quarterly 14(1):53-85.

http://dx.doi.org/10.1080/07418829700093221

Harpaz, Amikam and Sergio Herzog. 2013. "Police Officers' Acceptance of Community Policing Strategy in Israel and Their Attitudes towards the Arab Minority." Israel Affairs 19(1):191-213. http://dx.doi.org/10.1080/13537121.2013.748294

Hassell, Kimberly D. and Steven G. Brandl. 2009. "An Examination of the Workplace Experiences of Police Patrol Officers: The Role of Race, Sex, and Sexual Orientation." Police Quarterly 12(4):408-30.

http://dx.doi.org/10.1177/1098611109348473
Hensley, Christopher and Richard Tewksbury. 2005. "Wardens' Perceptions of Prison Sex." The Prison Journal 85(2):186-97. http://dx.doi.org/10.1177/0032885505276996

Herek, Gregory M. and Eric K. Glunt. 1993. "Interpersonal Contact and Heterosexuals' Attitudes toward Gay Men: Results from a National Survey." Journal of Sex Research 30:239-44. http://dx.doi.org/10.1080/00224499309551707

Johnson, Devon. 2008. "Racial Prejudice, Perceived Injustice, and the Black-White Gap in Punitive Attitudes." Journal of Criminal Justice 36:198-206. http://dx.doi.org/10.1016/j.jcrimjus.2008.02.009

Kanter, Rosabeth M. 1977. Men and Women of the Corporation. New York: Basic Books.

Kelling, George L. and Mark H. Moore.1991. "From Political to Reform to Community: The Evolving Strategy of Police." Pp. 1-26 in Community Policing: Rhetoric or Reality, edited by J. Greene and S. Mastrofski. New York: Praeger.

King, William R. 1999. "Time, Constancy, and Change in American Municipal Police Organizations." Police Quarterly 2(3):33864. http://dx.doi.org/10.1177/109861119900200305

Kostelac, Constance. 2008. "The Changing Face of Police Organizations: Trends in Civilianization." PhD dissertation, Arizona State University, Phoenix.

Lewis, Gregory B. 2003. "Black-White Differences in Attitudes toward Homosexuality and Gay Rights." Public Opinion Quarterly 67(2):59-78. http://dx.doi.org/10.1086/346009

Lyons, Philip M., Jr., Michael J. DeValve, and Randall L. Garner. 2008. 'Texas Police Chiefs' Attitudes Toward Gay and Lesbian Police Officers." Police Quarterly 11(1):102-17. http://dx.doi.org/10.1177/1098611107302655

Manning, P.K. 1984. "Community Based Policing." American Journal of Policing 3:205-77.

Manning, P.K. 1995. "Book Review: Forces of Deviance." Justice Quarterly 12:605-10.

Martin, Susan E. and Nancy C. Jurik.1996. Doing Justice, Doing Gender: Women in Law and Criminal Justice Occupations. Newbury Park, CA: Sage.

Mastrofski, Stephen D. and Richard R. Ritti. 1996. "Police Training and the Effects of Organization on Drunk Driving Enforcement." Justice Quarterly 13: 290-320. http://dx.doi.org/10.1080/07418829600092951

Messerschmidt, James W. 1993. Masculinities and Crime: Critique and Reconceptualization of Theory. Lanham, MD: Rowman \& Littlefield.

Monro, Surya. 2007. "New Institutionalism and Sexuality at Work in Local Government." Gender, Work \& Organization 14:1-19. http://dx.doi.org/10.1111/j.1468-0432.2007.00329.x

National Center for Women \& Policing. 2000. "Equality Denied: The Status of Women in Policing", available at: http://www.womenandpolicing.org/PDF/2000\%20Status\%20 Report.pdf (accessed 23 April 2013).

Nicholl, Caroline G. 1999. "Community Policing, Community Justice, and Restorative Justice: Exploring the Links for the Delivery of a Balanced Approach to Public Safety." Washington, DC: U.S. Department of Justice, Office of Community Oriented Policing Services.

Novak, Kenneth J., Leanne F. Alarid, and Wayne L. Lucas. 2003. "Exploring Officers' Acceptance of Community Policing: Implications for Policy Implementation." Journal of Criminal Justice 31(1):57-61. http://dx.doi.org/10.1016/S0047-2352(02)00199-X

Omi, Michael and Howard Winant. 1994. Racial Formation in the United States ( $2^{\text {nd }}$ ed.), New York City: Routledge.

Paoline, Eugene A. III, Stephanie M. Myers, and Robert E. Worden. 2000. "Police Culture, Individualism, and Community 
Policing: Evidence from Two Police Departments." Justice Quarterly 17(3):575-605.

http://dx.doi.org/10.1080/07418820000094671

Pelfrey, William V., Jr. 2004. "The Inchoate Nature of Community Policing: Differences between Community Policing and Traditional Police Officers." Justice Quarterly 21(3):579-601. http://dx.doi.org/10.1080/07418820400095911

Pratt, John. 2011. "Norbert Elias, the Civilizing Process and Penal Development in Modern Society." The Sociological Review 59(s1):220-40.

http://dx.doi.org/10.1111/j.1467-954X.2011.01986.x

Reisig, Michael D. and Roger B. Parks. 2000. "Experience, Quality of Life, and Neighborhood Context: A Hierarchical Analysis of Satisfaction with Police." Justice Quarterly 17(3):607-30. http://dx.doi.org/10.1080/07418820000094681

Ridgeway, Cecilia L. and Shelley J. Correll. 2005. "Limiting Inequality through Interaction." Contemporary Sociology 29:110-20. http://dx.doi.org/10.2307/2654936

Rosen, Steven A. 1980-81. "Police Harassment of Homosexual Women and Men in New York City: 1960-1980." Columbia Human Rights Review 12:159-90.

Rosenbaum, Dennis P. and Arthur J. Lurigio. 1994. "An Inside Look at Community Policing Reform: Definitions, Organizational Changes, and Evaluation Findings." Crime and Delinquency 40:299-314. http://dx.doi.org/10.1177/0011128794040003001

Scheff, Thomas J. 1966. Being Mentally III: A Sociology Theory. Chicago: Aldine.

Sims, Barbara, Kathryn E. Scarborough, and Janice Ahmad. 2003. "The Relationship between Police Officers' Attitudes toward Women and Perceptions of Police Models." Police Quarterly 6(3):278-97.

http://dx.doi.org/10.1177/1098611103254315
Trojanowicz, R.C. 1986. "Evaluating a Neighborhood Foot Patrol Program: The Flint, Michigan Project." Pp. 258-62 in Community Crime Prevention: Does It Work?, edited by D.P. Rosenbaum. Beverly Hills, CA: Sage.

Unnever, James D., Francis T. Cullen, and James D. Jones. 2008. "Public Support for Attacking the 'Root Causes' of Crime: The Impact of Egalitarian and Racial Beliefs." Sociological Focus 41:1-33. http://dx.doi.org/10.1080/00380237.2008.10571321

U.S. Department of Defense. 2012. "Annual Report on Sexual Assault in the Military", available at: http://www.sapr.mil/ index.php/annual-reports (accessed 17 June 2013).

U. S. Department of Defense. 2010. "Report of the Comprehensive Review of the Issues Associated with a Repeal of Don't Ask, Don't Tell", available at: http://www.defense.gov/home/ features/2010/0610_dadt/DADTReport_FINAL_20101130(se cure-hires).pdf (accessed 17 June 2013).

U.S. Department of Justice, Federal Bureau of Investigation. 2012. "Crime in the United States, 2011", available at: http://www. fbi.gov/about-us/cjis/ucr/crime-in-the-u.s/2011/crime-in-theu.s.-2011/police-employee-data (accessed 15 June 2013).

Yang, Alan S. 1999. From Wrongs to Rights: Public Opinion on Gay and Lesbian American's Moves toward Equality: 1973-1999. Washington, D.C.: National Gay and Lesbian Task Force Policy Institute.

Younglove, Jane A., Marcee G. Kerr, and Corey J. Vitello. 2002. "Law enforcement officers' perceptions of same sex domestic violence: Reason for cautious optimism." Journal of Interpersonal Violence 17(7):760-72. http://dx.doi.org/10.1177/0886260502017007004

Received on 18-06-2014

Accepted on 05-08-2014

Published on 23-09-2014

DOI: http://dx.doi.org/10.6000/1929-4409.2014.03.24

(c) 2014 Bernstein and Wulff; Licensee Lifescience Global.

This is an open access article licensed under the terms of the Creative Commons Attribution Non-Commercial License (http://creativecommons.org/licenses/by-nc/3.0/) which permits unrestricted, non-commercial use, distribution and reproduction in any medium, provided the work is properly cited. 